\title{
Entrevista com Mauricio Tenorio Trillo
}

\section{Interview with Mauricio Tenorio Trillo}

\section{Concedida a Helena Bomeny e Lucia Lippi Oliveira Rio de Janeiro, 25 de agosto de 2008}

Hoje, nos Estados Unidos, que questão mobiliza os historiadores e pensadores que trabalham com a América Latina?

- Hoje, pela primeira vez, observo uma coisa que acho que para as gerações anteriores não existia: há uma separação cada vez maior, com relação à história da América Latina, entre o que se faz nos Estados Unidos e o que se faz no Brasil, no México, na Argentina. Para explicar essa distinção, vou tentar descrever quais são os dois grandes temas, hoje, da história da América Latina.

Na América Hispânica, de dois, três anos para cá, há uma grande preocupação com o bicentenário das independências - de 1804 a 1830, todos os países se tornaram independentes -, mas sobretudo com a grande revolução da Nova Espanha e com a revolução do Rio da Prata, em 1810. Esse é o ponto de partida das grandes festas de comemoração do bicentenário que estão sendo preparadas. A par das preparações políticas, historiograficamente está havendo uma revisão, mais ou

Helena Bomeny é professora titular de sociologia da UERJ, pesquisadora do CPDOC/FGV e coordenadora geral da Escola de Ciências Sociais da FGV, Rio de Janeiro, Brasil (helena.bomeny@fgv.br). Lucia Lippi Oliveira é pesquisadora e professora do CPDOC/FGV, Rio de Janeiro, Brasil (lucia.lippi@fgv.br).

Est. Hist., Rio de Faneiro, vol. 22, n. 44, p. 539-554, julho-dezembro de 2009. 
menos sensata, do que foram os processos de independência. Há uma preocupação muito grande com uma nova história política - coisa que vocês, no Brasil, começaram 10 ou 15 anos atrás. Essa nova história política está muito ligada à história do direito, o que é interessante. Está muito ligada, sobretudo a historiografia do Rio da Prata e da Nova Espanha, a uma veia espanhola que antes não existia. Por razões óbvias, depois de 25 anos de democracia, há hoje na Espanha uma nova escola historiográfica, com gente como José María Portillo Valdés, Carlos Garriga e outros, que fizeram um grande esforço para estudar as raízes legais do Império dos Bourbon. Essa nova escola incluiu em sua temática não só a Nova Espanha e o tremendo big bang que a invasão napoleônica produziu na colônia, mas ainda outros temas, como o País Basco e a Catalunha. E com isso houve uma aproximação da historiografia hispânica com a historiografia espanhola, começando por um famoso historiador do México, François-Xavier Guerra, um filho de espanhóis que escreveu na França, e vários artigos muito influentes sobre a ideia de modernidade e de independência. Antes de se falar de história atlântica, coisa de que agora todo mundo fala, Guerra começou a tratar desses temas.

Estamos, assim, na América Hispânica, revendo a história política do período da independência, e essa revisão está afetando outros períodos. E uma das grandes virtudes dessa nova abordagem é que estamos vendo a independência de uma maneira menos nacionalista. Não se trata mais só da Nova Espanha, mas também do que se passou no Peru, na Argentina, na Espanha. Há vários tipos de interpretações, mas sem dúvida está-se abrindo o panorama para alguma coisa mais que México, que Argentina, e isso é bem-vindo. É uma história, também, que leva muito a sério as instituições. Pela primeira vez estamos realmente levando em conta a Constituição de 1812, os códigos, o modo como funcionava o Império, não estamos pensando nessas coisas apenas como fachadas que não serviam para nada em uma situação de opressão total. Os historiadores do direito estão participando disso. E isso também é bem-vindo. Os historiadores estão fazendo para o mundo hispânico uma história que já havia sido feita para o mundo luso. Como disse Tulio Halperín há muitos anos, já era tempo de explicar a política dos século XVIII e XIX como aquilo que foi, e não como aquilo que deveria ter sido. Sempre aprendemos que a política colonial era antimoderna, não funcionava. Agora, estamos vendo como ela funcionava. Porque funcionava, sem dúvida alguma. Foram três séculos de colônia. E a independência não foi um episódio em que alguns bárbaros ou alguns generais oprimidos se rebelaram porque queriam a liberdade e a igualdade. Ao contrário, foi um processo de quase 20 anos, em que a princípio ninguém queria a independência, mas em que todos, inevitavelmente, tiveram que caminhar para ela.

Essas são as virtudes dessa nova abordagem. É também uma abordagem que está olhando para a parte regional, para o que se passava nas várias regiões. A 
historiografia brasileira, devido ao federalismo com que nasceu o Brasil, já conhecia isso. Vocês não podiam estudar a independência do Brasil como se estudava a da Nova Espanha, porque lá a Cidade do México sempre foi onipresente, demasiado importante. Já no Brasil, desde o princípio se sabia que as regiões, como Minas, por exemplo, tinham seu interesse. Essa é outra virtude.

É claro que essa abordagem também tem seus problemas. Ela nos lembra, mais uma vez, a dificuldade que temos de falar da América Latina. Cada vez que resenho um novo livro sobre as independências, vejo que há sempre um artigo sobre Buenos Aires, outro sobre o México, outro sobre o Peru. Como esses estudos já são muito transatlânticos e estão muito ligados aos espanhóis, eles falam da Constituição de Cádiz e enveredam pela Espanha. E os Estados Unidos? E o Haiti? E o Brasil? Não que eu ache que sempre se deva abranger tudo. Mas se estamos falando de um big bang que começa em 1808/1809 e dura até 1815, se estamos falando do surgimento do mundo moderno, a partir das guerras napoleônicas, do colapso de vários impérios, do surgimento em massa dos Estados-nação, esse é um processo em que, efetivamente, a América não é só um objeto, só um ator passivo. Ela é um ator ativo, que está criando o conceito de Estado-nação moderno, que por sua vez vai influir na unidade italiana, na unidade alemã, na formação moderna da Espanha, da Inglaterra, em todos e em cada um desses novos processos.

Se esse é o tema, o problema é que nós nos vemos encurralados na categoria América Latina. É um corpete muito apertado. Por quê? Porque a América Latina nos limita a imperativos culturais e raciais dos quais temos de excluir os Estados Unidos. E entender o processo de independência sem os Estados Unidos é como tentar entender a explosão sem Napoleão. Os Estados Unidos fizeram a primeira grande revolução, foram o ponto de partida de muitas outras, foram uma referência constante. O Haiti representou um processo importantíssimo para todas as elites, e no entanto também é excluído da América Latina. O Brasil, como teve um processo de independência único, não é tratado. Como não houve mortos, passamos ao largo. Tudo isso é parte desse "corpete" América Latina. Minha ideia é que os bicentenários estão nos convidando novamente a dizer: na época das independências ocorreu um problema global muito importante na história do mundo ocidental - do mundo ocidental. Ponto. Por que estar discutindo Brasil, ou México, ou Argentina? Tudo isso é o mundo ocidental, é a Europa na América.

Essa sua maneira de ver põe em questão a própria noção de atraso. Ou seja, na criação dos Estados nacionais modernos, as Américas estariam à frente, e não atrás da Europa.

- Exato. Sempre repito uns versos que dizem: "e serei, mergulhado no passado,/ cada vez mais moderno e mais antigo". Graças a uma conferência para 
a qual Helena Bomeny me convidou, encontrei com Antonio Candido e perguntei-lhe de quem eram. Dom Antonio, que é uma enciclopédia ambulante, me disse que eram de Ledo Ivo. Os processos de independência são uma paráfrase constante desses versos. Quer dizer, para inventar uma nação, temos que mergulhar no passado; e, mergulhando no passado, seremos cada vez mais modernos e mais antigos. Quando alguém pergunta se o Brasil ou o México são modernos, a resposta deveria ser: depende de quando, como e com quem. Os processos podem ser modernos ou atrasados, dependendo das circunstâncias. Dizer que o México, ao se tornar um império em 1821, estava traindo a modernidade que impulsionava o processo de formação do Estado nacional é uma bobagem. Era tão moderno ou tão antigo quanto podia ser. A solução, naquele contexto, foi dizer "temos que salvar o Estado, nos tornar independentes”. Foi o que vários monarquistas nos Estados Unidos também disseram. O Canadá, por exemplo, permaneceu fiel ao rei. Por quê? Porque eram modernos, mas temiam a destruição do Estado. Acreditavam em uma modernidade de outro tipo, em que as estruturas monárquicas pudessem ser mantidas. Alguns americanos mais modernos, digamos Washington e Jefferson, lançaram-se ao excesso republicano, mas com uma instituição como a escravidão. Ou seja, onde está a grande modernidade? Por que eles são modernos? Por que não são vistos como atrasados?

O Brasil envolveu-se num modelo muito interessante. Graças ao fato de que toda a estrutura simbólica e administrativa do Império português estava no Rio, foi mais fácil fazer sobreviver as estruturas do Estado monárquico. Os brasileiros fizeram então o que México, Peru e Estados Unidos tentaram fazer até a entrada do século XIX, que era a independência, a representação, a modernidade, mas com o Estado vivo. Não podiam inventar outro, seria muito, muito perigoso. E não se enganaram. O México fracassou em seu império, os Estados Unidos fracassaram em sua tentativa monarquista, Lima fracassou, e seguiram-se 100 anos de grande instabilidade, incluindo a grande guerra civil norte-americana. Já o Brasil não sofreu a instabilidade das outras colônias.

Concluindo: para que serve a ideia de América Latina nisso tudo? Creio que a ideia de América Latina é uma peça a mais, que se pode tirar ou botar. Se estamos falando das independências, interessa a França, interessa a Espanha, interessam os Estados Unidos, interessa o Brasil, interessa tudo. Mas não interessa a ideia de irmandade latino-americana. É muito pouco interessante. Agora, se formos para o princípio do século XX e falarmos, por exemplo, do processo de industrialização, ou da paz que houve em todo o continente entre 1870 e 1929, caberia falar em América Latina. Não sei se seria tão útil, se pensarmos que Brasil e Argentina têm um processo de expansão unido à Europa, enquanto México e Estados Unidos têm uma história comum que tem muito pouco a ver com o Brasil nesse momento. Seria melhor ver a história mexicana como parte da história 
norte-americana ou a história norte-americana como parte da mexicana, e não tentar uni-la à brasileira. Tudo depende do momento de que falamos.

Quero terminar esta parte dizendo o que se passa, hoje, do lado da historiografia norte-americana. Aí manda a divina trindade: gender, race and class, gênero, raça e classe. São esses os temas que continuam interessando aos historiadores que fazem, em inglês, a história do Brasil, da Argentina, do México. São esses os temas que direcionam as pessoas. Não que não haja historiadores mexicanos interessados no tema raça. Mas quando eles escrevem uma tese em espanhol é muito diferente do que escrevem quando estão nos Estados Unidos. Os temas lá estão definidos por todo um processo acadêmico, intelectual e político de luta pelos direitos civis que se desenrolou nos anos 70, a tal ponto que muitas das teses parecem ser cópias de um mesmo modelo. Jamais nada muda de lugar: "Raça e gênero em San Pedro de Macoris, na República Dominicana", "Raça e gênero em Campos, no Brasil", "Raça e gênero em não sei onde"... É aborrecido, é chato, é uma novela de mistério lida de trás para frente. Você já sabe desde o início quem é o assassino. Não há nenhuma grande novidade.

Ao explicar como foi construída a noção de América Latina, Richard Morse diz o seguinte: o século XIX foi um tempo de grande competição do mundo anglo-saxão com o mundo francês, que inventou o conceito de América Latina justamente para se tornar mais próximo desse novo mundo. Por outro lado, já no século XX, a migração de vários intelectuais e pesquisadores da América Latina para os Estados Unidos possibilitou a criação dos Latin American Studies, que pipocaram por lá antes mesmo de surgirem nos países latino-americanos. Em sua opinião, os temas gênero, raça e classe são o que mantém hoje a unidade dos Latin American Studies?

-É uma pergunta muito boa. Escrevi um livro sobre o conceito de América Latina há uns oito anos, algo assim. Escrevi-o em espanhol e gostaria de reescrevê-lo em inglês. Eu acreditava que a ideia de América Latina havia-se mantido como um conceito acadêmico nos Estados Unidos graças a três coisas. Uma, o que você disse: que os exilados formaram comunidades, como já havia ocorrido em Paris ou em Nova Iorque, e foram essas comunidades, sobretudo de argentinos, uruguaios, alguns brasileiros, chilenos, que foram formando esse conceito. A segunda coisa, obviamente, foi a Guerra Fria e a Revolução Cubana, que fizeram com que muito dinheiro fosse aplicado na criação de centros de estudos a fim de conhecer o inimigo, estudá-lo. E a terceira coisa, que a meu ver é o que intelectualmente ainda mantém o conceito, é a ideia de que a América Latina é, primeiro, uma espécie de raça e, segundo, uma espécie de fracasso conjunto quer dizer, um não-Estados Unidos. Racialmente, os latino-americanos são raças mistas, são negros, são índios, são todos esses. A América Latina é outra civilização, ontologicamente antagônica à civilização norte-americana. 
Richard Morse também dizia isso.

- Sim, aprendemos isso com Morse nos anos 70. Creio que ele formulou isso de uma forma lúdica, porque também gostava do exotismo, adorava aquela outra civilização de mulatas, de jogo etc. E quando se faz isso, com todo o carinho de Morse, ou com todo o racismo de Huntington, cria-se uma ontologia: seja porque é valioso, seja porque é horrível, o outro é o oposto. Mas há ainda uma ideia mais tangível, para a qual participaram muitos economistas argentinos e brasileiros. A ideia de que, ante o progresso do pós-guerra, a América Latina era um exemplo de fracasso conjunto, era o lugar onde se tentaram todas as fórmulas, e todas fracassaram. Mas a América Latina se mantém como tal porque é o fracasso que, na realidade, não é fracasso. É o fracasso do qual ainda assim queremos falar, do qual falamos constantemente, no qual as grandes empresas norte-americanas investem, é o fracasso que não é África, não é outra região do mundo, é o lugar onde estão a décima, a nona e a oitava economias mundiais. Então, qual é o fracasso? Em duas gerações, Brasil, México, Chile e Argentina se transformaram em grandes economias; de sociedades agrícolas atrasadas passaram a sociedades industriais, com todos os problemas de Los Angeles, Chicago ou qualquer outra cidade americana. Mas, ainda assim, nos vemos como um fracasso conjunto. Por isso se mantém a ideia de América Latina: é o antagônico racial e o antagônico do fracasso conjunto frente ao êxito verdadeiro que é o modelo norte-americano.

Vocês me perguntam se é a trilogia gênero-raça-classe que mantém ou alimenta a ideia de América Latina, hoje, nos Estados Unidos. Creio que a relação é como entre o calor e o fogo. A América Latina sempre foi o outro antagônico racial. Imaginemos que as favelas estivessem cheias de pobres brancos. Os norte-americanos estariam tão obsessivamente interessados em estudá-las? Outro caso é o do México. Os americanos, desde 1880 até o último historiador que foi ao México, sempre disseram: "A Cidade do México não é o México. É muito moderna, é caótica. Temos que ir conhecer o verdadeiro México, lá onde estão os índios". Para eles, o México verdadeiro é o das pequenas comunidades indígenas. O resto não é México, eles não querem esse México. Quando eu estava no Centro de Estudos Latino-Americanos de Austin, que é o maior dos Estados Unidos, foi feita uma exposição das fotografias que os estudantes e os professores tinham feito durante as férias. As fotos exibidas eram de: uma índia carregando uma criança, pessoas com um arado no campo, favelados... Esses estudantes e professores chegaram ao aeroporto do Rio de Janeiro, ou de São Paulo, ou da Cidade do México, andaram pelas ruas dessas cidades, desfrutaram do álcool, das mulheres, dos homens, da rua, da comida, do sol, dos vícios, de tudo que havia, mas não tiraram nenhuma foto disso; só tiraram quando chegaram aos índios. Por quê? Porque isso é a América Latina, tudo mais é exceção. Em parte, é horrível, porque o que eles não consideram América Latina é muito parecido com o que vivem, com as ruas de Los Angeles, com as ruas de Chicago. É muito triste 
dizer isso, mas o Brasil não é esse Brasil que eles fotografaram, de miseráveis. O Brasil é uma sociedade extremamente complexa. O México não é um país de índios, de gente pobre, de narcotraficantes, de música horrorosa, de carros grandes... Mas através disso se mantém viva a ideia de raça.

Podemos aproximar essa ideia de América Latina da ideia de orientalismo, tal como a descreveu Edward Said - uma construção, uma leitura do Ocidente sobre o

Oriente?

- Sim, as duas ideias se parecem, mas com dois matizes. Também já escrevi sobre isso. Foi uma espécie de "orientalismo" que levou os Estados Unidos à criação e à sustentação da ideia de América Latina, através dos centros de estudos e da historiografia. Quando digo isso, por favor, não me interpretem mal: há excelentes estudos produzidos nos Estados Unidos. Por exemplo, a história do México: não se pode entender, nem escrever, nem ler, nem aprender a história do México se não se falar inglês, porque os grandes livros estão escritos em inglês. Estou falando da quantidade enorme de estudos sobre os temas que hoje mobilizam a historiografia nos Estados Unidos, e não de casos individuais. Assim como no Brasil, há bons e maus historiadores nos Estados Unidos. O que estou dizendo é que, se você for pesquisar na internet sobre "raça", ou "gênero", vão aparecer quilos de trabalhos, porque é isso que move a historiografia americana.

Feito esse parêntese, creio que os matizes dos "orientalismos" americano e europeu variam e são muito profundos. O primeiro é o seguinte. A Europaa Alemanha, a Espanha, a Inglaterra - fez da Índia, do Japão e da China o seu Oriente. É a mesma lógica dos Estados Unidos para com a América Latina. A diferença está em que a América Latina é um Ocidente - mas nunca se lhe concede essa categoria -e, além disso, é um Oriente de segunda, diferentemente de Japão, China e India. Ao escrever um artigo, o americano diria: Brasil é samba, pandeiro e abacaxi no turbante de Carmem Miranda, México é festa, sesta, sombrero e Frida Kahlo, e sempre serão assim. Já a China é tudo aquilo que é tradicional, masé também toda a produção internacional; Japão é gueixa, mas é também Sony e Hitachi. Já nós não mudamos. Embora o Brasil já seja um monstro industrial, continua sendo samba, pandeiro, abacaxi. Da mesma forma o México.

O que acontece? A sociedade não muda? Muda. Nossa sociedade já mudou enormemente. Somos sociedades de massas, de milhões de pessoas, sociedades industriais. Temos muitos pobres, mas muitos deles têm celular, têm televisão, são parte do mundo do consumo, como em qualquer lugar. E muitos deles, como acontece com o Brasil e o México, têm mais: têm uma experiência direta dos Estados Unidos. O “orientalismo", no caso do México, é quase tão difícil de manter quanto a pureza da língua - ninguém pode manter a pureza da língua, porque logo ela se contamina, e ninguém fala corretamente. Mas assim são os 
Estados Unidos. Querem manter o seu "orientalismo" frente ao México, quando, depois das cinco da tarde, têm o México em qualquer edifício das suas cidades. Por que fazer "orientalismo" em relação a Tepoztlán, a Chiapas, se, quando os escritórios americanos fecham a porta, quem os limpa é um mexicano? Há 1,4 milhão de mexicanos em Chicago, há 11 ou 12 milhões de mexicanos nascidos no México em todos os Estados Unidos. Onde está o diferente? Onde está o exótico? No entanto, isso se sustenta. Mas com esse caveat, com esse matiz: somos um Oriente de segunda, porque não somos Japão, não somos China, não somos Índia. E, como Oriente de segunda, estamos destinados a ser estudados de maneira diferente do que foi a China. Para um alemão se tornar um sinólogo, ele tem que aprender 40 formas de chinês, passar 30 anos estudando. Enquanto isso, em um verão você produz um brasilianista. $O$ sujeito vem aqui, fica encantado com a baía de Guanabara, estuda dois anos de português e vira brasilianista... É que somos um Oriente de segunda, não somos um Oriente de primeira. E nunca chegaremos à categoria de Ocidente.

Esse é o primeiro matiz do "orientalismo" americano em relação à América Latina. O outro, que para nós é muito mais difícil de falar, é que nós mesmos fizemos dos Estados Unidos um Oriente. Também inventamos um "orientalismo" que nos obrigou a não conhecer os Estados Unidos e a viver de estereótipos. É a reprodução da mesma lógica. Para os mexicanos, é uma coisa quase ridícula. Como é possível que em um país que é vizinho dos Estados Unidos, que tem 12 milhões de nacionais vivendo lá, que, depois do petróleo, vive do dinheiro que mandam os mexicanos lá residentes, não se estude os Estados Unidos?! Ninguém estuda os Estados Unidos no México! Pouquíssimas pessoas. Não há um doutorado sobre os Estados Unidos, não há quem estude a história dos Estados Unidos. Como é possível isso? Como vocês, brasileiros, nós vivemos de estereótipos: o do americano gordo, feio, ignorante etc. Também construímos um "orientalismo". E eu diria mais: creio que isso é mais uma questão das elites do que das massas, porque para estas, no caso do México, os Estados Unidos são uma vivência diária. Na cidade onde eu nasci, por exemplo, todo maior de 18 anos já esteve nos Estados Unidos, pelo menos uma vez, trabalhando, e alguns foram e nunca voltaram. Para todos, os Estados Unidos são uma realidade.

Da mesma forma como não temos uma perspectiva mexicana, brasileira, argentina, dos Estados Unidos, tampouco temos - a não ser quando estamos nos Estados Unidos - uma perspectiva da América Latina. Há historiadores mexicanos que estão reescrevendo a história da independência, e quando digo que temos de considerar o caso brasileiro, eles respondem: "Para quê? Não tem nada a ver”. Não sabem, nem querem saber nada sobre o Brasil. Não tive experiência no Brasil, mas estou certo de que o mesmo acontece por aqui. Não se conhece muito sobre o México, as bibliotecas não têm livros sobre o México, assim como as bibliotecas do México têm pouquíssimos livros sobre o Brasil. Não sabemos nada 
uns dos outros. Não é que tenhamos de saber em razão da unidade bolivariana. Temos de saber porque é importante, porque é interessante, porque é parte da história. Não sabermos nada sobre nossos vizinhos, não sabermos nada sobre os Estados Unidos e falarmos de América Latina quando estamos nos Estados Unidos é uma fórmula perfeita para manter viva a ideia de América Latina, com essas obsessões raciais e de fracasso conjunto.

Você mencionou há pouco o Canadá. É outro país que nós, aqui no Brasil, ignoramos completamente. É como se não fizesse parte do território do "Novo Mundo".

- Pois é. Nos anos 80, porque os Estados Unidos iam assinar um tratado de livre comércio com a América do Norte, incluindo o Canadá e o México, os governos começaram a dar dinheiro aos historiadores para fazerem histórias conjuntas. Não durou muito. Para os mexicanos, era dificílimo encontrar um canadense. Até escrevi um artigo - citando uma antiga canção mexicana que aconselhava "quem encontrar um amor, cuide dele" - dizendo: quem encontrar um canadense, cuide dele. Porque é muito difícil encontrar um canadense para um projeto conjunto e conseguir dinheiro. Eu queria escrever, e ainda quero, se não um livro, ao menos um ensaio que fale sobre a América do Norte como ideia. Mas tive que parar, exatamente porque não sabia nada sobre o Canadá. Nos últimos três ou quatro anos estive lendo a respeito, e o que percebi é que o continente está imprensado, como um sanduíche, entre dois grandes exemplos monárquicos, dois grandes exemplos de estabilidade, no sentido de conservadorismo e temor a mudanças, em meio a radicalismos de todo tipo. Até hoje, quando você assina um papel com o governo canadense, está assinando com Sua Majestade britânica. Que era o que José Bonifácio queria, e conseguiu por quase cem anos: ser uma commonwealth portuguesa, com a continuidade sanguínea da coroa.

Penso que a história canadense tem muito que ensinar ao continente. Nós já nos introduzimos na história dos Estados Unidos e vimos as lições que podemos aprender com isso. Mas na história do Canadá, não. No México, não se conhece nem Canadá, nem Brasil. Não acho possível ser especialista em tudo, mas não custa nada ter uma visão geral da história brasileira, uma visão geral da história canadense. O Canadá tem muito que ensinar. Por exemplo, não são os Estados Unidos os pioneiros no multiculturalismo, é o Canadá. Inclusive, muitas instituições são copiadas das canadenses. E não nos voltamos para o Canadá.

Você se formou em ciências sociais, mudou para a história e, nesse momento, foi para os Estados Unidos, onde se dedicou à área de América Latina. Como foi esse seu trajeto intelectual pessoal?

Gostaria de lembrar um caso, porque também não quero parecer ingrato. Uma vez, estava eu em um congresso em Londres sobre arte e nacionalismo, 
dizendo essas barbaridades que estou dizendo aqui, sobre rever a ideia da América Latina como festa, sesta, sombrero e abacaxi de Carmen Miranda, quando uma historiadora alemã me disse: "Sim, mas tudo o que você disse, você pôde dizê-lo exatamente por causa de todas essas pessoas que você está criticando. Se não fosse por essas pessoas, que deram espaço, que começaram a falar de América Latina e a lutar por raça e por classe, você não teria voz em uma mesa como esta". O que era verdade. Quer dizer, antes de entrar em minha história pessoal, devo dizer que a academia norte-americana não só me abriu a possibilidade de conhecer sobre o Brasil, o Canadá, os Estados Unidos, o México, como me deu um lugar para fazê-lo. Um lugar em que às vezes me sinto incômodo, em que às vezes sinto que continuo sendo o Mexican talker que fala sobre o México, porém, um lugar. Um lugar que não sei se seria possível conseguir no Brasil, no México ou na Argentina. Devo dizer isto, e está dito.

Em relação à minha trajetória pessoal, sou um mexicano de classe média que em princípios dos anos 80 foi para a universidade pública no México. Tive uma identificação com os anos 60 muito diferente daquela que os brasileiros, ou argentinos, ou chilenos puderam ter por terem vivido sob ditaduras. Diferentemente da minha geração no Brasil e na Argentina, eu convivi com os brasileiros, argentinos e chilenos que estavam exilados no México, e que evidentemente eram pessoas muito peculiares. Na falta de nome melhor, eram sixties boys e sixties girls. Então minha geração surgiu, nos anos 80 , com o que eu chamaria de uma lágrima artificial. Nós aprendemos nas salas de aula a chorar 1968, a chorar os sixties. Mas não era um gesto honesto, porque nós não vivenciamos aquilo. E não era honesto em dois sentidos: nem entendíamos o que significava 68 , porque não vivenciamos, nem nos sensibilizava haver uma geração que lutou por alguma coisa, drogas, liberação etc. Nós estávamos numa crise econômica e tratávamos era de sobreviver. Não podíamos lutar, porque se você lutasse não tinha o que comer, e maconha, você podia fumar em casa, não era problema. Mas nós todos choramos. Essa geração nos ensinou essa lágrima artificial de 68 - artificial para nós, não quero dizer que o fosse de fato. Mas aquela não era a nossa épica, era algo aprendido na sala de aula. Nossa épica foi a da crise, do "salve-se quem puder". Não era grupal. Não éramos os garotos dos anos 80 . Não era aquela coisa dos anos 60 , de todos juntos. Esta é a primeira marca.

Os exilados nos ensinaram muito marxismo, de todos os gostos e cores, mas sobretudo europeu. Eu tive que ler não só o Manifesto comunista trinta mil vezes, como os gurus todos: Althusser, Poulantzas, Gramsci, tudo aquilo. Eu, nos anos 80, na universidade pública mexicana, entrando nas ciências sociais pela sociologia, comecei por essa identificação com 68 , com o marxismo e com os exilados, e evidentemente, por um momento, me deslumbrei. Porém, num segundo momento, senti que era muito difícil continuar, porque, do ponto de vista 
da épica, aquela não era a minha luta, aquele não era o mundo que eu estava vivendo. A revolução não era algo que eu via na esquina. Perto de mim, o que eu via era a inflação, que comia o salário do meu pai, e a necessidade de sobreviver. Não havia aquela coisa de classe média unida, lutando, todos muito bem educados. Era outra vida. O próprio marxismo também já era um marxismo muito decaído, nas nossas universidades empobrecidas, onde os professores quase não apareciam nas salas de aula. Tudo era muito dogmático. Tanto que, a não ser no último ano, e fora das aulas, nunca me deram Weber para ler. Era Marx, Marx e Marx.

Nesse contexto, eu descobri a história, porque, como bons historicistas, meus professores usavam a história como matéria-prima para tudo o que diziam. Se queriam falar de luta de classes, falavam do 18 Brumário. Na verdade, estavam me contando uma história. E era quando contavam a história que eu os entendia. Eu me pegava lendo as enciclopédias, vendo o que aconteceu em 1851, lendo livros sobre história francesa, para ver o que tinha acontecido e, por conseguinte, entender Marx. Quando me diziam: "Faça um trabalho sobre o conceito de mais-valia em Marx", eu tinha que ler a história da industrialização e da enclosure na Inglaterra. E eu me via, novamente, às voltas com as enciclopédias. Até que um dia eu disse a mim mesmo: a história é a matéria-prima disso tudo; por que não me tornar um distribuidor de matéria-prima, em vez de matéria já feita? E comecei a ler história. Naquela época havia uma grande crise no México, não davam bolsas para se estudar fora, mas, graças a uma bolsa da Organização dos Estados Americanos, consegui ir para os Estados Unidos. E ao chegar aos Estados Unidos, com a minha formação, com a língua que eu falava, inevitavelmente, fui colocado no campo da América Latina. O que foi bom. Mas também posso dizer que, em alguns momentos, me sinto apertado, preciso sair um pouco dali.

Não havia problema de um graduado em ciências sociais fazer pós-graduação em história nos Estados Unidos?

Se houvesse, teria sido no México. Nos Estados Unidos não, porque a formação do tipo undergraduated e bachelor é muito geral. Depois vai-se para a pós-graduação e aí é que se decide o campo. Então, para os padrões norte-americanos, eu era mais um. Mas devo dizer que, além de Marx e da identificação com 68 , outra coisa me marcou quando eu era adolescente na Cidade do México, estudante de uma universidade pública. Vou dizer outra barbaridade e vocês vão me desculpar. Eu não aprendia muito com meus professores. Eu aprendia nas ruas, com as leituras dos jornais, dos livros que havia. A vida cultural da cidade era muito marcada pela presença de Octavio Paz e sua revista, que se chamava Vuelta. E na revista Vuelta, ainda jovem, com 17, 18 anos, comecei a ler traduções de um louco chamado Richard Morse, que falava de história, da herança colonial no pensamento hispânico, das diferenças civilizacionais entre o Brasil e os Estados 
Unidos. Li um artigo dele traduzido em um espanhol belíssimo, por um poeta, e quis conhecer esse homem, ler esse homem. Também traduziam autores de ciências sociais, e assim comecei a buscar, fora do campo do marxismo, que era o me davam nas aulas, outras leituras. Felizmente, acho que o primeiro problema do marxismo era a sua prosa, que era pouco sedutora. E fora do marxismo encontrávamos prosas muito interessantes, que nos diziam coisas, mas que não eram lidas nas universidades. Eu tinha que ler escondido, porque aquilo era fascista, não se devia ler. Mas era muito bonito e muito interessante. Para uma pessoa da minha geração, isso começou a ser história, e começou a me mostrar o que eu queria ser. Por isso, quando pensei em sair do México, eu quis ir para o lugar onde estava Richard Morse. Acabei em Stanford, porque o catálogo da universidade dizia que ele estava lá. Mas quando cheguei, havia já dois anos que ele tinha saído...

Em Stanford tive uma formação muito rigorosa de historiador, ao estilo norte-americano, muito empírico, pela qual - repito - agradeço. E lá me chegou, nos anos 90, a revolução teórica da historiografia norte-americana. Stanford foi o centro do debate sobre "the Western canon", "the Western civilization". Todos começaram a ler Foucault e Derrida, todos estávamos nisso. Posso dizer que, em algum momento, esse pós-moderno me seduziu. Eu lia tudo o que se produzia, Hayden White, aquela coisa toda. Gostei muito, até que me cansei e parei de segui-los. Mas foi muito importante. E também tive a sorte de estar no centro dessa revolução no momento em que ela estava ocorrendo. Aconteceu comigo uma coisa, que acredito que com muitos cientistas sociais e muitos historiadores não aconteceu, que é muito pessoal. Minha entrada foi a sociologia, foi o marxismo, foi Octavio Paz, foi Richard Morse, tudo isso, mas houve outra ainda, que agora posso ver, que era a linguagem, a prosa.

\section{A literatura.}

A literatura. Para a qual me voltei, inevitavelmente. E isso, que pode tornar alguns loucos ou mandá-los para o céu, a mim me manteve preso a sempre tentar contar uma história. $O$ vínculo com a literatura evitou que eu voasse a céus teóricos, porque sempre quero contar uma história, a minha história.

Os historiadores em geral não gostam de Hayden White, que é mais valorizado pelos críticos literários. Mas para você o vínculo entre história e literatura não é um problema.

Não. O problema que os historiadores tiveram com muitas dessas discussões se deveu aos excessos havidos com o pensamento pós-moderno. Mas também é verdade que muitos historiadores, que são mais fiéis à disciplina do que eu, que se assumem como científicos, como pessoas que dizem a verdade, ficam aborrecidos quando alguém lhes diz que o que fazem é pura prosa. Eu sem- 
pre soube que o que eu fazia era prosa. Não tenho nenhum problema em aceitar isso. $\mathrm{O}$ que não quer dizer que qualquer coisa que eu faça é boa. Da mesma maneira que nem todo romancista é um grande romancista. Ou que um adolescente que rabisca três linhas é poeta. Mas todos tentam. Não tenho problema com isso. Não quer dizer que eu compartilhe de tudo o que Hayden White e os outros dizem. Sempre dou para ler aos meus alunos os textos teóricos da história, mas também lhes ensino duas coisas muito importantes, que me ajudaram a contar uma história sem problemas, sem me preocupar se inventar história era certo ou não. São dois pequenos conselhos.

O primeiro é entender que o que Hayden White faz é uma maneira de sentar-se à mesa com alguma coisa que não tem fim e não tem solução. A pergunta que Hayden White faz é a pergunta que se fez Hegel, que se fez Benedetto Croce, que se fez Nietzsche - é sobre o tema da História e o saber do passado, uma pergunta que não tem fim. Se quisermos falar disso, vamos nos sentar à mesa $\mathrm{e}$ vamos falar. E não se trata de ler Hayden White, o último artigo de Derrida, o último qualquer coisa. Trata-se de sentar-se e abrir um diálogo. Não há solução possível. A única é: sente-se para conversar e aprenda sobre esses assuntos.

O problema é que os que se sentam a essa mesa, modernamente, nunca escrevem história. Uma coisa é Benedetto Croce, que escrevia teoria da história e também grandes livros, preciosos livros de história. Outra coisa é Hayden White, que, de história, escreveu pouco. A maioria dos norte-americanos e franceses, incluindo Ricoeur ou De Certeau, todos os dias estão escrevendo um último livro sobre o passado, mas nunca escreveram um livro de história, nunca contaram uma história, como contam a seus filhos. Têm de falar da teoria antes de contar a história. Eu sempre digo aos meus alunos: "Sigam o conselho de minha filha de cinco anos: 'não explica a história, conta a história"'. É claro que é preciso fazer-se algumas perguntas, que mudam a forma como você conta a história. Não posso contar a história tão ingenuamente, mas também não posso dizer que não se pode contar. Na hora de contar, tenho de contar. Sempre digo aos meus alunos: "Somos uns romancistas de imaginação muito pobre. Precisamos de muitos dados para contar uma história".

Outra coisa é que não há fórmula. Weber é Weber porque recebeu influência de Hegel, e porque é Weber, porque veio da sua família. Benedetto Croce e os grandes historiadores - Braudel, Sérgio Buarque de Holanda - são o que são por suas leituras, por suas famílias, por seus vícios. A fórmula não se repete. É uma soma de muitos processos de estocagem, que leva a que este homem tenha esta prosa, tenha estes dados e escreva esta história. E isso é um milagre que cada historiador cuida de reproduzir. Nem todos temos êxito. Mas reconhecer a importância do que disse Hayden White não elimina a nossa ciência, a nossa arte. Lucia Lippi me presenteou com um livro onde a primeira frase de um capítulo é: 
"Quando dizemos patrimônio, dizemos herança". Ou: quando dizemos história, dizemos herança. Por alguma razão que não sei explicar, continuamos precisando da história. As pessoas a demandam hoje, e a demandarão amanhã e depois de amanhã. É muito difícil responder à pergunta filosófica sobre por que precisamos da história, se, na realidade, ninguém sabe história. Noventa por cento das pessoas vivem sem história. Mas a demandam, e eu não sei por quê. E nós, os historiadores, vivemos desse não sei por quê.

Realmente, sempre que paramos para pensar vemos que precisamos da história.

Sim. Creio que escrever história é como colecionar enigmas - riddles, em inglês -, com dados e com imaginação. O bom historiador tem de guardar em sua gaveta muitos enigmas, para poder contar a história. Ele não poderá contá-la com todos os enigmas, mas se não os tiver guardados em sua gaveta, será fatal. Por isso os grandes historiadores são grandes criadores, no sentido artístico e literário do termo. Gosto muito da imagem de Robert Musil em O homem sem qualidades, onde ele fala do ensaio como uma água-viva no mar, cheia de enigmas que incitam a imaginação. Se você a tira da água e a põe na areia, ela não é nada, é um corpo enrugado; não resta nada daquela maravilha. É isso que o historiador faz quando lê Hayden White e solta a imaginação. Mas, para contar uma história, que é necessariamente sequencial - a, b, c, d, f-, ele tem de deixar muitas coisas de fora. A única forma de fazer isso é ter a gaveta de enigmas. É saber como é a água-viva na água e tentar tirá-la de lá. Nessa tentativa, alguns têm êxito, deixam alguma coisa viva na água-viva, mas outros não. E isso é a História. Por isso ela é bonita, por isso continuamos a fazê-la, por isso, quando ela existe, como a poesia, é como se sempre tivesse estado ali, e por isso precisamos dela. Um bom livro de história, ao qual todos se referem, até para refutá-lo, é necessário.

Entre os historiadores da América Latina, Tulio Halperín é uma figura interessante.

Sim. Tulio, desde a sua geração até a minha, foi o único historiador de língua espanhola com o qual pudemos aprender uma história geral da América Latina. Quase todos nós, antes de saber inglês, lemos seu livro História contemporânea da América Latina, que primeiro foi publicado em italiano e depois em espanhol foi a pedido dos editores italianos que ele o escreveu. Tulio é um historiador muito interessante, porque, por exemplo, é profundamente argentino, mas conhece muito do Brasil, do México, de outros países. Temos pouquíssimos historiadores que escrevem em castelhano. Quase todos os livros sobre América Latina que você vê hoje, escritos em português, são coleções de ensaios, em que escrevem vários ao mesmo tempo. Lígia Prado, em São Paulo, conseguiu escrever uma história geral em português. Mas nós todos temos uma dívida com Tulio, em castelhano e em português. Em inglês existe muita coisa, alguma coisa em francês. 
Tulio tem uma visão da história muito global, mas também muito de história política. Sem dúvida, esses mestres já não se fazem mais. Já não há como produzi-los. Como disse um político mexicano, a cavalaria está muito fraca... Eu me incluo nisso, porque não me sinto capaz de fazer um livro como o dele. É complicado, é difícil. Além disso, eu não sei se gostaria. Preferiria um livro sobre as Américas incluindo o Canadá, incluindo os Estados Unidos. Ou um livro sobre as independências que incluísse o Haiti. Um livro sobre a industrialização teria de incluir a Alemanha, a Inglaterra. Falar sobre a imigração implicaria falar pouco do México e falar muito do Brasil, da Argentina, dos Estados Unidos e do Canadá, no mesmo livro. Eu preferiria isso a um livro sobre América Latina.

Em sua opinião, nós, latino-americanos, ganhamos pouco com a invenção da América Latina? Ela foi mais limitadora do que criadora?

É uma pergunta muito interessante. E para alguém que se beneficiou tanto da ideia de América Latina, contestá-la, de uma maneira ou de outra, é traição. Continuo a crer que é uma categoria que está aí e que deve ser usada de acordo com o momento. Mas não deve mandar nas nossas investigações, não deve regê-las. Acho que isso já está passando. A realidade histórica muda todo dia. Não me surpreenderei que daqui a 30 anos o Brasil seja mais discutido - como já começa a ser - junto com Índia, Rússia e China, e que México e Estados Unidos sejam parte de uma história comum. Não me surpreenderei, e não sei por que deveríamos nos espantar. É normal. É assim. E se há motivo para espanto, só podemos culpar os historiadores. Somos nós, os historiadores, que temos vivido dessa coisa etérea chamada América Latina, cheia de caminhos raciais e culturais, sem conhecer nada do Brasil, sem conhecer os Estados Unidos. Somos culpados disso, por vivermos histórias nacionalistas, de um lado, e histórias cheias de estereótipos “orientalistas”, de outro. Não há razão para colocarmos uma barreira de proteção à ideia de América Latina. Se ela morrer, que morra.

Por curiosidade: na academia norte-americana, a questão da Amazônia está presente?

Sim. É um campo do qual não falamos muito, mas de que o Brasil, graças a Warren Dean, participa muito. A história ecológica. E a Amazônia, exatamente pelas preocupações ecológicas, está sendo muito discutida, acho que de uma maneira muito interessante. Por um lado, existe o problema, natural, de questões ecológicas e biológicas das espécies etc., que são discutidas de modo muito interessante, porque muitos dos cientistas e pesquisadores da Amazônia até hoje são estrangeiros, e também brasileiros. E os biólogos, os botânicos etc., todos estão integrados. Não há sequer o problema de língua, pois todos escrevem em inglês. Esses estão e sempre estiveram unidos. 
Em termos da História, existe uma divisão, porque há aí uma questão política. Todos querem manter a Amazônia, todos querem protegê-la. E existe também a ideia de que "vocês acabaram com tudo, e agora não deixam que nós nos modernizemos; por que vocês acabaram com tudo, e nós não temos o direito de acabar com tudo?” Existe aí um problema, um jogo muito grande. Mas é um tema que, desde os anos 80 , começa a aparecer. Antes, era somente raça. Mas agora, cada vez mais, os temas da Amazônia, da ecologia e do Brasil começam a entrar. Warren Dean foi o grande historiador que introduziu tudo isso. E falou da natureza de uma maneira global, muito interessante. E aí, pouco a pouco, foi-se abrindo um campo. Já temos estudantes. Já tenho alunos que estão fazendo a história do fenômeno $E l$ Niño, a história da Antártica. E esse será o tema, por excelência, que romperá as barreiras nacionais, por necessidade. Mas acho que isso pode nos ensinar, porque há outros temas, que assumimos como nacionais, que são como a ecologia. O próprio tema da raça. Por que o assumimos como um tema tão nacional, quando ele é tão internacionalmente definido? $\mathrm{O}$ que não quer dizer que temos que tratar dele como nos Estados Unidos. O problema é que a definição de raça é muito nacionalista, dos Estados Unidos, não é que a definição racial não seja internacional. Não é preciso falar de raça como nos Estados Unidos para entender que é um conceito que se define globalmente. 